\title{
On Hawthorne's Feminist Ideas Reflected in The Scarlet Letter
}

\section{Li Guanghua}

Institute of Foreign Languages, Shandong University of Technology, Zibo, Shandong, China, 255049

\begin{abstract}
Hawthorne was a feminist forerunner, which is largely due to the influences exerted on him by women who were close to him. By examining his fictional portrayal of Hester in The Scarlet Letter, the author finds that Hawthornemade a subversive woman his spokesperson voice his feminist ideas and refute the concept of manhood and masculinity of his day.
\end{abstract}

Keywords—feminist ideas, Hester, manhood, The Scarlet Letter.

\section{INTRODUCTION}

Nathaniel Hawthorne (1804-1864), the great literary genius in American literature during the Age of Romanticism, earns his fame mostly through his fiction: The Scarlet Letter.

It is well known that Hawthorne was a feministforerunner, who exposes his sympathy for women in The Scarlet Letter, the most powerfully feminist fiction in the $19^{\text {th }}$ century America.

When Hawthorne was brewing his writing of The Scarlet Letter, the Feminist Movement was building up to an unprecedented height in America. Inspired by some radical feminist advocates, particularly by Margaret Fuller,aninfluential feminist theorist, Hawthorne luckilyaccessed the most profound feminist ideas. His mounting awareness of women's rights gave rise to his new sensitivity to women's right, and Hawthorne began to express great sympathy for women victimized by wrongs against their sex in his works.

\section{SOME INFLUENTIAL WOMEN IN HAWTHORNE'S LIFE}

Nina Baymonce saidthat:“...the question of woman is the determining motive in Hawthorne's work",(1)which can be best interpreted by the significant roles played by women throughout his life and his career as well. Hawthorne had been writing successfully for extraordinarily talented women of letters whose creative minds had helped him shape his own works. It would have been incredible if
Hawthorne had not understood and penned the great variety of women around him who inspired and urged him to make their concerns a visible reality in his works.

Hawthorne's father died when he was four years old,and he had to spend his boyhood in his mother's extended family, growing up among various talented and supportive females. They were Hawthorne's first-handed source of good literary material, productive collaborators, faithful readers, rigorouseditors, fair-minded critics and emotional and financial supporters.

Hawthorne's aunt Mary Manning, though uneducated, helpedhim become the first college graduate in the family and started him on his career as a professional writer.

His mother Elizabeth Hathorne, though highly cultivated by reading, had to depend on her relatives financially after her husband died young, whichmanifested the cruel reality toHawthorne: women had no legal right of inheritance, and thus had to live at the mercy of men.

Hawthorne started his lifelong pattern of writing for women when he was thirteen. In his early literary activities, Hawthorne teamed his sisters, who were both colleagues and collaborators in his efforts to become a successful writer.

Before getting married, Hawthorne spent most of his days writing and walking and chatting with his elder sister Elizabeth who played a leading role in his developments as a writer. Elizabeth, an educated writer by extensive reading, was not only an intelligent and sophisticated reader of 
Hawthorne's literary creation but also his competitor spurring him on to his early publishing attempts.

Hawthorne lived in Salem after he graduated from college during which he made acquaintance with more capable and intelligent women, Susan Ingersoll who was his friend and potential social activist hiding runaway slaves. Susan Burley who attracted men of letters with her literary salons in Salem, to mention just a few, all offeredHawthornefascinating women to know about and to write for.

The womenfrom Peabody family in Salem - Mrs. Elizabeth Peabody and her daughters, Elizabeth, Mary, and Sophia- were all as interested in Hawthorne's literary careers as the women in Hawthorne's own family. In addition, they, the first three in particular, were radical feminists and educators as well, who went even further as to set up schools to educate women. Their imprint of feminist ideas on Hawthorne can be detected in Hawthorne's later works.

Hawthorne's wife, Sophia Peabody, was his assistant and critic in his later literary career. Hawthorne always read his manuscripts to her before he sent them off to be published. No wonder Hawthorne regarded his wife's grievous headaches as triumphant success when he read the conclusion of The Scarlet Letter to her.(2)

With so many talented, active and supportive women with him, Hawthorne automaticallyfelt quite positive about women. He saw these women as his first and most valued readers and portrayed their lives first sympathetically, approximately until the time of his marriage. In his early stories such as Young Goodman Brown, the female characters represent important values, but they are seen from the outside, their inner worlds are not of any concern to Hawthorne.

However, after Hawthorne married Sophia Peabody and became a lot closer to Elizabeth Peabody, and to their friend, Margaret Fuller, he aquatinted the women of Salem and Boston, radical advocates of Women's Right Movement. Female figures under his pen became increasingly complex as he knew women better and became aware of what feminists were fighting for and dreaming of.

When Hawthorne's friendship with Fuller deepened, Fuller began toexercise more power over Hawthorne's imagination which he would struggle with much of his life. In fact, during Fuller's five-year friendship with Hawthorne, she played a very significant role in Hawthorne's opinion about women and in his literary creation of women. Witnessing the injustices imposed on women andwomen's changing lives, Hawthorne graduallychanged his point of view on women's issues and even came up with the idea that if society is to be changed for the better, such change will be initiated by women.

\section{HESTER'S MISFORTUNES}

Hawthorne's sympathy for women in his own life finds its way into the shaping of characters inThe Scarlet Letter, in whichhelent much sympathy to his heroine, Hester Prynne. By depicting Hester's tragic life and her fighting, Hawthorne refutes the concept of manhood and masculinity of his day.

When her story unfolds in "The Market Place", she is sentenced to wear the shameful scarlet letter $\mathrm{A}$ on the bosom of her dress, exposing her sin to the merciless public.Thetortureis sohumiliating that few human beings can ever bear.As the story advances, Hawthorne says that legal as Hester's marriage, it is completelyunreasonable for Hester is young and elegant, while her legal husband, Roger Chillingworth, old and deformed. Roger Chillingworth, a magician on the verge of modern science, has an old, intellectual belief in the dark science. He is neither Christian, nor selfless aspire,but the representative of male authority who has nothingbut intellectual belief in himself and his male authority.

"But one can not keep a wife by force of an intellectual tradition",(3)therefore, Hester is doomed to fall in love with another man worthy of her love.

As Hawthorne presents at the prison interview, it is Chillingworth, instead of Hester, who acknowledges the injustice imposed on Hester.

"Mine was the first wrong, when I betrayed thy budding youth into a false and unnatural relation with my decay..."(4)

What Hawthorne wants to convey is that Hester's marriage is not based on mutual love. As Hester admits that "thou knowest that I was frank with thee, I felt no love, nor feigned any",(5) she had beenlured to marry her beauty to Chillingworth's fortune before she was able to 
understand the meaning of true love.

Hester's marriage might be a perfect match in the eyes of the public in the $17^{\text {th }}$ century New England. But only Hester knows it means nothing but misery to her. Her sin,to a great extent, is the unavoidableconsequence of her ill-matched marriage.

According to the male authority then, the relationship between husbands and wives was similar to that between God and the puritans, so a wife's betrayal of her husband was similar to a puritan's betrayal of God. In addition, wives, the private possessions of their husbands, should live at the mercy of their husbands. In Hawthorne's opinion, since Chillingworthadmitts his sin, he is supposed to show understanding and sympathy to Hester and Dimmesdale. But Hawthorne, determined to make Chillingworth the worst sinner ever, has Chillingworth abandon his lawfully wedded wife, withdrawhis name from the roll of mankind and practice the outward forms of the local religion with no inward conviction. ... In one word, Hawthorne makes a fiend out of a learned, not unkind scholar.In doing so, Hawthorne dumps his disgust on the fiendish victim of the adultery, the defender of the dying moral norm, and the maintainer of male authority.

Since Hester violates the $7^{\text {th }}$ Commandment, she has to be subject to the punishment of the male authority and the condemnation of the public. The male authority was a group of old males represented by the Governor which surrounds itself with displays of power. Hawthorne seems to speak highly of the old ruling males when he says it was a period when the forms of authority were felt to possess the sacredness of Devine institutions, but his conclusion betrays him. With the development of the story, Hawthorne's satire of the ruling males escalates. Hawthorne makes a sharp contrast between the dying, old system represented by the Governor's residence and the irresistible growth of new things represented by the pumpkin.The residence of Government Bellingham, imposing as it is, is dying irresistibly.To Hawthorne, the male rulers are hypocriticalin that in their private life, they are not whatthey pretend to be in public.

So it is Hester's tragedy to be subject to the trial of the male rulers, theleastqualified to judge human passion. It's heartbreaking for readers to witnessHester's loss or, to be more exact, her intentional concealmentof her naturally female beauty.

The worse misfortunecomes from Hester's true loverDimmesdale. It seems that Dimmesdale's youth, knowledge, fame and social status is a perfect match for Hester's youth and elegance. But it is the very true fact that makes Hester's suffering even more unbearable for Hester loves a man who devotes himself to God instead of her.

Although Hawthorne is not hesitant to show his sympathy for Hester and goes further to speak in defense of her love, to Dimmesdale, Hawthorne shows more condemnation thansympathyby contrasting the fragility of a devalued male with the toughness of a powerful female.

Dimmesdale, a brilliant young minister with a great expectation, is destined to be suppressed by a community possessing the qualities of aging public males. In order to make himself a pet of the oligarchs, Dimmesdale has to hold back his flaming passion inside. His sin is nothing but an impulsive release of self-disciplined energies against the restrictions imposed on the young by the aging rulers. What he does is human nature, and nothing is wrong. But the problem is Dimmesdale is more pious to his God than he is faithful to his lover. He is a coward, and a hypocrite, too. Unlike Hester, who never doubts the sacredness of her love and is ready to protect her lover at any price, Dimmesdalefirmly believes that he betrays his God forhe breaches what he preaches. But henever screws up his courage to stand on the scaffold with his beloved and their daughter to face the public condemnation, let alone go back into town with his family, hand in hand.

Dimmesdaleis sinned to try hard to conceal his sin, therefore, it is his fate to be constantly tortured physicallyandspiritually. Throughout the romance, there are some occasions on which the distracted young minister is empowered to redeem himself from his sin. But the self-aware sinneris never willing to seizeany opportunity. For him, if the end of his life has meant anything, it must have meant eternal joy achieved through a righteous union with his God, his people, and the things of this universe.

Throughout Hester's seven solitary years, Dimmesdale is addicted to his self-reflection and self-torture, satisfied by indulging himself in lashing his own white, thin, spiritual savior's body. It never occurs to him what his lover and his daughter might be suffering. 
Hawthorne speaks ruthlessly the hypocrisy of Hester's lover, unveiling the destructive effect of Puritan belief, which is, in essence, the root cause of Hester's tragic romance.

At the end of the story, the godly minister is at the verge of breaking down physically and spiritually. But when Hester comes to his rescue unexpectedly and urges him to flee to a new country to live a new life, Dimmesdalerefuses for he thinks he is too weak to go alone. And he believes that there is no new country, no new life waiting for him. What's worse,Dimmesdale dies a glorious death, leaving a speech killing Hester's hope for brand new life, and changing Hester's 7-year waiting into nothing.In sharp contrast to the weak man, Hester stands out as a tough woman who survives the public condemnation, and exerts great influence upon her hypocritical and cowardly lover.

Hawthorne's stand is self-evident: the cowardice and hypocrisy of manhood contribute to Hester's tragic romance.

\section{HESTER'S REBELLION}

In The Scarlet Letter, Hawthorne takes the wholly original step of fashioning a "fallen" woman, a dark heroine, who stands in sharp contrast to the so-called learned, virtuous males. If Hester is guilty, she must be a feminist criminal bound by a link of mutual crime with a man whose cowardiceonly serves as a foilto her brevity. She is a sensual woman who has, in Hawthorne's words, "a rich, voluptuous, oriental characteristic and who is bold enough to whisper to her lover:" "What we did had a consecration of its own."'(6)

Hester is a sinner at the beginning, and a feminist exemplar in the end, who dares to brood over women's wrongs and dreams of revolutionizingthe relationship between men and women. She eventually dismantles the stigma andwins the respects of her fellow puritans by her angelic quality and the practical ability to help others as a charity worker and an adviser. She is, in one word, a feminist in advance of the season.

1. Hester's Meditation on her Misfortunes

When Hester Prynne's begins, she emerges from her prison cell holding her newborn baby, the product of her "sin", with the humiliatingletter A upon her breast.Although
Hester behaves as best a woman might under themountingstress of a thousand unrelenting eyes fastened upon her bosom, she feelsgenuinelyguilty in the presence of her legal husband, Chillingworth, and therefore, allows him to conceal his real identity in order to track down Hester's fellow sinner.

As the story advances, while Chillingworth isconverting himself into a real sinner, Hester is growing in meditation on women's right. Hawthorne makesgreat changes take place inside Hester. In light of her soul-marriage to Dimmesdale, her sexual relationship withChillingworth, in Hester's eyes, is a degrading experience.She concludes that she is nothing but the victim of an ill-conceived marriage.

She says bitterly: "it seemed a fouler offense committed by Roger Chillingworth, than any that had since been done him, that in the time when her heart knew no better, he persuaded her to fancy herself happy at his side". "Yes, I hate him!" "He betrayed me!" "He has done me worse wrong than I did him." "Be it sin or no, I hate the man!"(7)

By describing Hester's increasing awareness of her own ill-conceived marriage, Hawthorne shows growing concern to women's issues as a whole.While speaking pitifully of a less guilty wife, Hawthornecondemns pitilessly a more sinful husband.

In her early years of solitudes, Hester is targeted for verbal abuse and scorn by the clergy, the town folks, and children as well. At the very beginning, she is tortured by the sting of punishment inflicted on her. But time witnesses gradual changes in her. Outwardly, she becomes willing to wear the humiliatingletter. Inwardly, she lives in her speculations, her solitude, her quiet hours with her girl and her needlework... And by needlework, she wins self-relianceand independence of any man, which separates her from other women of her time. It is the veryscarlet letter that serves as her passport into realms where other women dare not to tread.

Hester's meditation goes beyond her own tragedies. Whenshe spends more time on reflection and introspection, she develops her own way of thinking, whichempowers her todetect the root of her tragedies, andto declare her rejection of public law and morality. She makes a big step toponder on women's lot in life, wonderingwhetherlife is 
worth accepting even for the happiest.

She dreams of a brighter period, when the world should have grown ripe for it, the whole relation between man and woman will be established on a surer ground of mutual happiness. (8)

It is self-evident that Heater is Hawthorne's spokeswoman who becomes a radical thinker engaged in a revolutionary fight against an established male authority. Her revolutionary thought sheds light on the possibility of the overthrow of government, ancient prejudice and ancient principle.

\section{Hester's Fighting in Action}

Hawthorne's characterizationof a subversive woman is achievedby her rebellious thought and martial actions. Hester first confronted with Governor Bellingham to defend her right to raise her baby who is everything to her for the baby isthe only treasure purchased with all she had, and the only thing to connect her parents forever.

When words reach her ears that some of the leading inhabitants have decided to deprive her of her child simply because they can notentrust such an immortal soul as Pearl to the guidance of a woman who has stumbled and fallen amid the pitfalls of the world.Hester steps out of her solitary cottagewithout any hesitation, confronting the old puritan magistrates with extraordinary courage and rebellious spirit.Shehas long been isolated from her fellow human beings, and she is very conscious that it is an unequal match between the Puritan magistrates and herself, but she wins her indefeasible rights to take care of her own baby.

Hester's second rebellious action is to exposeChillingworth's true identity, which signals her maturity.Seven years earlier, Chillingworth tried making a deal with Hester in prison which would allow him to cover his true identity. Since bothDimmesdale's life and fame were in the hand ofChillingworth, there seemed to be no alternative for Hester, but to acquiesce in his scheme of disguise. She agreed only because she was not in the right position to find a better way toprotecther lover. Moreover, at that time she didn't have the faintest idea of Chillingworth'smotive. But when she witnessed the suffering her lover struggled against, or, to be more accurate, had stopped struggling against, and saw that he wasat the edge of lunacy, she took immediate action to stop Chillingworth from hurting Dimmesdale any moreat any price.

Hester's third rebellion is to urge her lover to start a new life with her in the wildness. Dimmesdale, a pious minister, thinks that he can go nowhere for he is wretched and sinful andcan drag on his earthly existence only in the sphere where Providence has placed him. To strike light into the dark world of Dimmesdale, Hester, without the least hesitation, tears the scarlet letter off her bosom and throws it away, and next, she heaves a long, deep sigh, in which shame and anguish departs from her soul. When she eventuallytakes off the ugly cap defying the established norm of the Puritan society, her sex, her youth, and the whole richness of her beauty all come back to life.

\section{CONCLUSION}

In conclusion, influenced and inspired by women close to him, Hawthorne grew aware of women's sufferings and was, therefore, sympathetic to woman. In The Scarlet Letter, Hawthorne made a subversive woman his spokesperson who dares to challenge manhood and dares to dream of a society in which men and women are equal.

\section{REFERENCES}

[1] Nina Baym, Thwarted Nature: Nathaniel Hawthorne as Feminist. In: American Novelists Revisited: Ed. Pritz Fleischmann. Boston: G. k. Hall, 1982. 36.

[2] Henry James, Hawthorne 1879, In The Scarlet letter, Text, sources, Criticism.Ed. Kenneth S. Lynn. New York: Harcourt, Brace \& world, Inc., 1961. 175.

[3] D. H. Lawrence, Nathaniel Hawthorne and The Scarlet Letter 1923, In The Scarlet letter, Text, sources, Criticism.Ed. Kenneth S. Lynn. New York: Harcourt, Brace\& world, Inc., 1961. 192.

[4] Kenneth S. Lynn (ed.), The Scarlet letter, Text, sources, Criticism. New York: Harcourt, Brace \& world, Inc., 1961. 41,91,144,92. 